\title{
Comparison of antemortem clinical diagnosis and postmortem findings in burn-related deaths
}

\author{
Harun Tuğcu, M.D., ${ }^{1}$ Fatih Zor, M.D., ${ }^{2}$ Mehmet Toygar, M.D., ${ }^{1}$ Hüseyin Balandız, M.D. ${ }^{1}$ \\ ${ }^{1}$ Department of Forensic Medicine, Gulhane Military Medical Academy, Ankara \\ ${ }^{2}$ Department of Plastic, Reconstructive and Aesthetic Surgery, Gulhane Military Medical Academy, Ankara
}

\begin{abstract}
BACKGROUND: Burn injuries are an important public health problem resulting in high morbidity and mortality. Mortality in burn patients is associated with age, the extent of the burn surface, and the presence of concurrent chronic diseases. Studies have revealed differences between antemortem clinical diagnoses and postmortem findings in burn-related deaths.

METHODS: In the present study, postmortem examination reports and autopsy reports issued by the Department of Forensic Medicine in Gülhane Military Medical Academy between I January 1994 and 30 May 2013 were retrospectively reviewed together with patient charts in an attempt to compare postmortem findings and antemortem clinical findings in burn-related deaths.

RESULTS: In a period of approximately 20 years, thirty-one $(6.9 \%)$ of the deaths among 450 cases were burn-related. Of the injuries, $90.3 \%$ were caused by flame burns. Mean burn percentage was $70.52 \%$, and the survival of these cases was found to decrease significantly with increasing burn percentage $(r=-0.491, p=0.005)$. According to autopsy findings, pneumonia was the most frequently overlooked antemortem clinical diagnosis, and mortality was associated with systemic organ failures.
\end{abstract}

CONCLUSION: Burn-related deaths are an important cause of mortality among soldiers. We believe that postmortem findings revealed by autopsies could significantly contribute to the treatment of burn cases, and that interdisciplinary data sharing would be important in this respect.

Key words: Autopsy; burn injury; soldiers.

\section{INTRODUCTION}

Burn injuries are a significant public health problem associated with high morbidity and mortality. ${ }^{[1-4]}$ In a comprehensive study in Europe, the incidence of major burns was reported to be $0.2-2.9$ per 100,000 individuals, with flash burns, scalds, and contact burns being the most common types of burns, and higher mortality being associated with older age, the extent of the burns, and the presence of chronic diseases. ${ }^{[5]}$

Although burn-related mortality rates have decreased in recent years due to advances in the treatments provided by burn centers, the actual cause of mortality in burn-related

Address for correspondence: Hüseyin Balandız, M.D.
GATA Adli Tıp Anabilim Dalı Başkanlığı, 060 I0 Etlik, Ankara, Turkey
$\begin{array}{ll}\text { Tel: }+90312-3044867 & \text { E-mail: hbalandiz@gata.edu.tr } \\ \text { Qucik Response Code } & \begin{array}{l}\text { Ulus Travma Acil Cerrahi Derg } \\ \text { 20I5;2I(6):49I-495 } \\ \text { doi: } 10.5505 / \text { tjtes.20I5.36604 }\end{array} \\ & \text { Copyright 20I5 }\end{array}$

deaths has still not been fully elucidated. ${ }^{[6]}$ The comparison of antemortem and postmortem findings has revealed differences between antemortem clinical diagnoses and autopsy findings. ${ }^{[6-8]}$

Autopsy may show unexpected or unrecognized clinical findings, and the data obtained from autopsy can be used to elucidate future problems experienced by the patients.

In the present study, post-mortem examination reports and autopsy reports issued by the Department of Forensic Medicine in Gülhane Military Medical Academy between I January 1994 and 30 May 2013 were retrospectively reviewed together with the patient charts in an attempt to compare postmortem findings and antemortem clinical findings in burn-related deaths.

\section{MATERIALS AND METHODS}

The Turkish Armed Forces is one of the largest and the strongest military forces with respect to personnel number. The Department of Forensic Medicine in Gülhane Military Medical Academy is the only unit within the body of Turkish Armed Forces that routinely performs autopsies due to sol- 
dier deaths of a forensic nature.

In the present study, post-mortem examination reports and autopsy reports issued by the Department of Forensic Medicine in Gülhane Military Medical Academy between I January 1994 and 30 May 2013 for patients, in which cause of death was burn-related, were retrospectively reviewed together with the patient charts. The study was approved by the Ethics Committee of Gülhane Military Medical Academy.

In addition to demographic data of the cases, type of burns, burn percentage, and clinical findings were compared and statistical analyzes were performed.

Descriptive statistics included number (\%) and mean standard deviation for continuous variables. The Spearman correlation coefficient was calculated to indicate correlations, and a $\mathrm{P}$ value $<0.05$ was considered as statistically significant. SPSS I5.0 for Windows Evaluation Version was used in statistical analyses.

\section{RESULTS}

Among the four hundred and fifty cases that underwent postmortem and autopsy examinations in the Department of Forensic Medicine in Gülhane Military Medical Academy between I January 1994 and 30 May 20I3, thirty-one (6.9\%) deaths were found to be burn-related. Of these cases, nineteen $(61.3 \%)$ were from the ground forces, nine $(29 \%)$ were from the gendarmerie, two $(6.5 \%)$ were from the naval forces, and one (3.2\%) was from the air forces.

All cases were male, and mean age was $22.9 \pm 5.9$ (min: 20, max: 45) years. Trauma, after sustaining an accident, was the most common finding in $\mathbf{8 7 . 1 \%}$ of the cases, and twelve cases $(38.7 \%)$ underwent autopsy. Of the injuries, $90.3 \%$ were caused by flame burns.

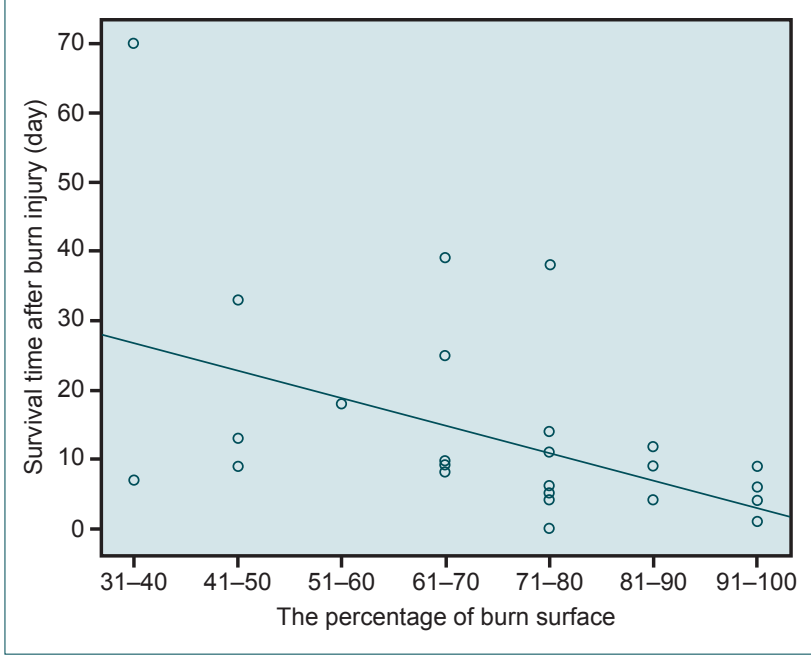

Figure 1. Relationship between body percentage of burn and survival.
Table I. Characteristics and demographic features of the cases

\begin{tabular}{lc}
\hline Patient characteristics & Data \\
\hline Number of cases & 31 \\
Mean age & $22.9 \pm 5.9$ \\
& $(\min : 20$, max: 45$)$ \\
Autopsy & $12(38.7 \%)$ \\
Mean percentage of burn surface & $70.52 \%$ \\
Flame burn & $90.3 \%$ \\
Inhalation burn & $13(41.9 \%)$ \\
Survival time after burn injury (days) & $13 \pm 14.4$ \\
\end{tabular}

Table 2. Characteristics of the injuries of the cases

Demographic data of patients and characteristics of injuries

\begin{tabular}{lcc}
\hline & $\mathbf{n}$ & $\%$ \\
\hline $\begin{array}{l}\text { Distribution of burned areas in the body } \\
\text { Head and neck }\end{array}$ & 29 & 93.5 \\
$\quad$ Trunk & 23 & 74.1 \\
Back & 26 & 83.8 \\
Upper extremities & 31 & 100 \\
$\quad$ Lower extremities & 31 & 100 \\
Manner of death & & \\
$\quad$ Suicide & 4 & 12.9 \\
$\quad$ Accident & 27 & 87.1 \\
Type of Burn & & \\
$\quad$ Flame burn & 27 & 87.1 \\
$\quad$ Flame burn + Scalding & I & 3.2 \\
$\quad$ Electricity burn & 3 & 9.7 \\
Tracheostomy & II & 35.5 \\
Fasciotomy & 12 & 38.7 \\
\hline
\end{tabular}

Inhalation injury was observed in thirteen cases (41.9\%), and mean length of hospital stay after the incident was $13 \pm 14.4$ (min: 0, max: 70) days. Demographic characteristics of the patients are shown in Table I.

Burn injuries most commonly occurred in autumn, and there was no significant seasonal difference $(p=0.079)$. Characteristics of injuries and the presence of fasciotomy and tracheostomy are shown in Table 2 .

Mean burn percentage was $70.52 \%$, and the survival ratio of the cases decreased significantly with increasing burn percentage $(r=-0.491, p=0.005)$. The survival ratio decreased 
Table 3. The comparison of clinical findings and postmortem findings in patients who sustained burn injuries

\begin{tabular}{|c|c|c|c|c|c|c|c|}
\hline No & Age & Type of burn & $(\%)^{*}$ & Day** & Clinical course & $\begin{array}{l}\text { Clinical diagnosis } \\
\text { and treatment }\end{array}$ & Postmortem findings \\
\hline I & 21 & Flame burn & 61 & 9 & $\begin{array}{l}\text { Fasciotomy and escharotomy, } \\
\text { mechanical ventilation }\end{array}$ & $\begin{array}{l}\text { Inhalation burn, } \\
\text { renal failure }\end{array}$ & Pneumonia \\
\hline 2 & 23 & Flame burn & 33 & 7 & $\begin{array}{l}\text { Escharotomy, } \\
\text { high fever }\end{array}$ & $\begin{array}{l}\text { Wound infection } \\
\text { (pseudomonas), } \\
\text { Antibiotherapy }\end{array}$ & $\begin{array}{l}\text { Sepsis (Citrobacter } \\
\text { Freundii) }\end{array}$ \\
\hline 3 & 21 & Flame burn & 42 & 33 & $\begin{array}{l}\text { Escharotomy and grafting, } \\
\text { high fever, } \\
\text { growth in culture } \\
\text { (pseudomonas) }\end{array}$ & Antibiotherapy & Pneumonia \\
\hline 4 & 21 & Flame burn & 84 & 4 & Fasciotomy & - & Pulmonary edema \\
\hline 5 & 21 & $\begin{array}{l}\text { Flame burn + } \\
\text { scalding }\end{array}$ & 80 & 4 & $\begin{array}{l}\text { Fasciotomy, } \\
\text { mechanical ventilation }\end{array}$ & $\begin{array}{l}\text { Inhalation burn } \\
\text { renal failure }\end{array}$ & \\
\hline 6 & 21 & Flame burn & 82 & 12 & $\begin{array}{l}\text { Fasciotomy, homografting, } \\
\text { high fever, } \\
\text { mechanical ventilation }\end{array}$ & $\begin{array}{l}\text { Inhalation burn, } \\
\text { renal failure }\end{array}$ & $\begin{array}{l}\text { Pneumonia } \\
\text { Tubular necrosis }\end{array}$ \\
\hline 7 & 21 & Flame burn & 92 & 4 & $\begin{array}{l}\text { Fasciotomy, } \\
\text { mechanical ventilation }\end{array}$ & Inhalation burn & Pneumonia \\
\hline 8 & 21 & Flame burn & 80 & 5 & $\begin{array}{l}\text { Fasciotomy, } \\
\text { mechanical ventilation }\end{array}$ & $\begin{array}{l}\text { Inhalation burn, } \\
\text { renal failure }\end{array}$ & Pulmonary edema \\
\hline 9 & 27 & $\begin{array}{l}\text { High voltage } \\
\text { electricity burn }\end{array}$ & 75 & 6 & $\begin{array}{l}\text { Fasciotomy, } \\
\text { Mechanical ventilation }\end{array}$ & - & $\begin{array}{l}\text { Electricity injury findings } \\
\text { in skin samples }\end{array}$ \\
\hline 10 & 21 & $\begin{array}{l}\text { High voltage } \\
\text { electricity burn }\end{array}$ & 48 & 9 & Mechanical ventilation & $\begin{array}{l}\text { Maxillofacial fractures, } \\
\text { pneumocephalia }\end{array}$ & $\begin{array}{l}\text { Electricity injury findings } \\
\text { in skin samples }\end{array}$ \\
\hline 11 & 21 & Flame burn & 70 & 8 & Fasciotomy, grafting & Antibiotherapy & $\begin{array}{l}\text { Pneumonia, } \\
\text { Pulmonary edema }\end{array}$ \\
\hline 12 & 22 & Flame burn & 42 & 70 & Mechanical ventilation & $\begin{array}{l}\text { ARDS, } \\
\text { antibiotherapy }\end{array}$ & $\begin{array}{l}\text { Pulmonary edema } \\
\text { Pneumonia }\end{array}$ \\
\hline
\end{tabular}

*: Total body burn surface area; **: Length of hospital stay.

with increasing age; however, this relationship was not found to be statistically significant $(r=-0.015, p>0.935)$ (Fig. I).

The survival period was 14.45 days among patients who required tracheostomy, and 12.20 days among those who did not. Mann-Whitney $U$ test did not indicate a statistically significant difference between these two groups $(p=0.493)$.

Patients who underwent fasciotomy survived for 8.42 days on average, while patients who did not undergo fasciotomy survived for 15.89 days on average. Mann-Whitney $U$ test did not indicate a statistically significant difference between these two groups $(p=0.759)$.

The comparison of antemortem diagnoses and postmortem findings in twelve cases who underwent autopsy revealed pneumonia diagnosis in six of the cases (50\%) (Table 3).

\section{DISCUSSION}

In developing countries, burn-related deaths often occur within younger age groups. ${ }^{[1,3,9,10]}$ In developed countries, on the other hand, such deaths are more common among children and the elderly. ${ }^{[, 11]}$ This age difference can be explained by the implementation of more effective preventive measures and greater availability of treatment options in developed countries.

Mean age has been reported as $36.6^{[2]}$ and $40 .\left.\right|^{[12]}$ years in studies in burn-related injuries and deaths in Turkey. In the present study, mean age was 22.9 years; therefore, burn-re- 
lated injuries and deaths are observed more commonly in a younger age group. As it is known, the study center is a military hospital, and most of the patients are military personnel in the army. Higher frequency of burn-related injuries and deaths among the younger population can be explained by the large population of young individuals in Turkey, and the fact that military service is compulsory for all males reaching a certain age.

Burn-related injuries often occur as a result of accidents. $[1,2,710,13]$ Among the burn-related deaths observed in the present study, $87.1 \%$ were caused by accidents while $12.9 \%$ were caused by suicide. It has been reported that $14-15 \%$ of deaths occurring among females in India are associated with burns, ${ }^{[3]}$ and suicide associated burn injuries rank third with a frequency of $\mathrm{I} I .4 \% .^{\left[{ }^{[0]}\right.}$ According to the study by Büyük et al., suicide has been associated with $6.3 \%$ of burn cases. ${ }^{[2]}$

Within a period of 20 years, $6.9 \%$ of the deaths evaluated in this study were caused by burns. Similar studies have reported a burn-related mortality ratio of $2.0-19.4 \% .^{[1,2,9,14]}$ These studies have reported no difference between military and civilian mortality rates, and it has been reported to be ranging between $5 \%$ and $10 \%{ }^{[14,15]}$ The fact that burn-related deaths were reported as an important public health concern in India explains the variability in the frequency of burn-related deaths in the literature..$^{[1,3,9]}$

Flame burn is the most common cause of burns, ${ }^{[1,6,7]}$ and it has been reported to be often accompanied by inhalation burn. $\left[{ }^{[1,14]}\right.$ In parallel to the literature, flame burns were the most common type of burn in the present study, with a frequency of $90.3 \%$, while inhalation burns were observed in thirteen of the cases (4I.9\%).

Major risk factors for mortality in burn-related injuries include older age, large burn surface area, and presence of concurrent diseases. ${ }^{[5]}$ In the study by Kumar et al., burn percentage was greater than $40 \%$ in $92.52 \%$ of the cases ${ }^{[1]}$ while in the study by Krishnan et al., ${ }^{[1]}$ mean burn percentage was determined as $43.7 \%$. In the literature, various studies have reported a mean length of hospital stay of 10.7 days, ${ }^{[6]} 26.4$ days, ${ }^{[1]}{ }^{[1]} 3.5$ days, ${ }^{[14]}$ and 16.9 days. ${ }^{[7]}$ Mean length of hospital stay was thirteen days in the present study. The cases were young patients who did not have concurrent chronic conditions that could affect burn-related mortality. Therefore, systemic organ failures that developed following burns were within the main causes of mortality in the current series of the cases.

Mean ratio of the burned area was $70.52 \%$ in the present study. Survival ratio decreased with increasing percentage of the burned area ( $r=-0.491, p=0.005)$ (Fig. I). In addition, survival ratio decreased with increasing age; however, the difference was not found to be statistically significant $(r=-0.015$, $\mathrm{p}>0.935)$.
In the study by Kallinen et al., it has been determined that the upper extremities and trunk are the most commonly affected areas of the body, that $38.5 \%$ of the patients undergo tracheostomy, and that the patients undergo an average of 2-3 operations. ${ }^{[6]}$ All patients evaluated in the present study had burns on the lower and upper extremities (Table 2).

Mean survival period was 14.45 days among patients who required tracheostomy, and 12.20 days among those who did not. Using Mann-Whitney $U$ test, no statistically significant difference was identified between tracheostomy and the survival period $(p=0.493)$. Patients who underwent fasciotomy survived for 8.42 days on average, while those who did not, survived for an average of 15.89 days. Mann-Whitney $U$ test showed no statistically significant difference between fasciotomy and the survival period $(p=0.759)$.

Mortality in burn patients is associated with multiple organ failure, sepsis, prolonged stay in the intensive care unit, and extended use of mechanical ventilation. ${ }^{[6]}$ Multi-organ dysfunction and sepsis are associated with burn percentage, age and gender ${ }^{[1,6,9]}$ According to autopsy findings, pulmonary injury and sepsis were found to be the most common reason of death in all age groups. Edema and congestion have been reported to be worsening with increasing age. ${ }^{[16]}$

Multi-organ failure associated with sepsis was found to be the primary cause of death, and Pseudomonas was the most commonly reported microorganisms in septic patients. Thanks to the increasing expertise of burn centers, advances in first aid services, and early treatment of burn patients, mortality among severe burn patients has gradually decreased. ${ }^{[1]}$

It was previously reported that clinically unrecognized findings revealed by autopsies could make significant contributions to the treatment of burn cases by clinicians. ${ }^{[6,8,16]}$ Studies have revealed differences between antemortem clinical diagnoses and postmortem findings in burn-related deaths. ${ }^{[6]}$ In the study by Kallinen et al., autopsy has revealed findings in $14.1 \%$ of the cases that were not found on antemortem examination, and pneumonia was the most common diagnosis during autopsy. ${ }^{[6]}$ The autopsy findings in the present study showed that pneumonia was the most common diagnosis that remained clinically unrecognized. The comparison of antemortem diagnoses and postmortem findings in twelve cases who underwent autopsy revealed pneumonia diagnosis in six of the cases (50\%) (Table 3 ).

In conclusion, burn-related injuries are an important cause of mortality in military populations, as well as the general population. We consider that the findings revealed by autopsies could make significant contributions to the treatment of burn cases and that interdisciplinary data sharing would be important in this respect.

\section{Conflict of interest: None declared.}




\section{REFERENCES}

1. Kumar V, Mohanty MK, Kanth S. Fatal burns in Manipal area: a 10 year study. J Forensic Leg Med 2007;14:3-6. CrossRef

2. Büyük Y, Koçak U. Fire-related fatalities in Istanbul, Turkey: analysis of 320 forensic autopsy cases. J Forensic Leg Med 2009;16:449-54. CrossRef

3. Sanghavi P, Bhalla K, Das V. Fire-related deaths in India in 2001: a retrospective analysis of data. Lancet 2009;373:1282-8. CrossRef

4. Roberts G, Lloyd M, Parker M, Martin R, Philp B, Shelley O, et al. The Baux score is dead. Long live the Baux score: a 27-year retrospective cohort study of mortality at a regional burns service. J Trauma Acute Care Surg 2012;72:251-6.

5. Brusselaers N, Monstrey S, Vogelaers D, Hoste E, Blot S. Severe burn injury in Europe: a systematic review of the incidence, etiology, morbidity, and mortality. Crit Care 2010;14:R188. CrossRef

6. Kallinen O, Partanen TA, Maisniemi K, Böhling T, Tukiainen E, Koljonen V. Comparison of premortem clinical diagnosis and autopsy findings in patients with burns. Burns 2008;34:595-602. CrossRef

7. Kallinen O, Maisniemi K, Böhling T, Tukiainen E, Koljonen V. Multiple organ failure as a cause of death in patients with severe burns. J Burn Care Res 2012;33:206-11. CrossRef

8. Fish J, Hartshorne N, Reay D, Heimbach D. The role of autopsy on patients with burns. J Burn Care Rehabil 2000;21:339-44. CrossRef

9. Sharma BR, Harish D, Singh VP, Bangar S. Septicemia as a cause of death in burns: an autopsy study. Burns 2006;32:545-9. CrossRef
10. Padubidri JR, Menezes RG, Pant S, Shetty SB. Deaths among women of reproductive age: a forensic autopsy study. J Forensic Leg Med 2013;20:651-4. CrossRef

11. Krishnan P, Frew Q, Green A, Martin R, Dziewulski P. Cause of death and correlation with autopsy findings in burns patients. Burns 2013;39:583-8. CrossRef

12. Cömert SS, Acar H, Doğan C, Cağlayan B, Fidan A. Clinical, radiological and bronchoscopic evaluation of inhalation injury cases treated at a burn center. [Article in Turkish] Ulus Travma Acil Cerrahi Derg 2012;18:111-7. CrossRef

13. Tümer AR, Akçan R, Karacaoğlu E, Balseven-Odabaşı A, Keten A, Kanburoğlu C, et al. Postmortem burning of the corpses following homicide. J Forensic Leg Med 2012;19:223-8. CrossRef

14. Gomez R, Murray CK, Hospenthal DR, Cancio LC, Renz EM, Holcomb JB, et al. Causes of mortality by autopsy findings of combat casualties and civilian patients admitted to a burn unit. J Am Coll Surg 2009;208:348-54. CrossRef

15. Wolf SE, Kauvar DS, Wade CE, Cancio LC, Renz EP, Horvath EE, et al. Comparison between civilian burns and combat burns from Operation Iraqi Freedom and Operation Enduring Freedom. Ann Surg 2006;243:786-95. CrossRef

16. Pereira CT, Barrow RE, Sterns AM, Hawkins HK, Kimbrough CW, Jeschke MG, et al. Age-dependent differences in survival after severe burns: a unicentric review of 1,674 patients and 179 autopsies over 15 years. J Am Coll Surg 2006;202:536-48. CrossRef

\section{ORIJIINAL ÇALIŞMA - ÖZET}

\section{Yanığa bağlı ölümlerde antemortem klinik tanılar ve postmortem bulguların karşılaştırması Dr. Harun Tuğcu, ${ }^{1}$ Dr. Fatih Zor, ${ }^{2}$ Dr. Mehmet Toygar, ${ }^{1}$ Dr. Hüseyin Balandız ${ }^{1}$}

${ }^{1}$ Adli Tıp Anabilim Dalı, Gülhane Askeri Tıp Akademisi, Ankara

${ }^{2}$ Plastik, Rekonstrüktif ve Estetik Cerrahi Anabilim Dalı, Gülhane Askeri Tıp Akademisi, Ankara

AMAÇ: Yanığa bağıı yaralanmalar, yüksek morbidite ve mortaliteyle sonuçlanabilen önemli bir halk sağlığı sorunudur. Yanık hastalarında mortalite; yaşıııı, yanık alanı yüzdesinin geniş olması ve kronik hastalıkların birlikteliği ile ilişkilidir. Yapılan çalışmalar, yanığa bağı ölüm olgularında premortem klinik teşhisler ile postmortem bulguların farklıık gösterdiğini ortaya çıkartmıştır.

GEREÇ VE YÖNTEM: Bu çalışmada, I Ocak 1994 ile 30 Mayıs 2013 tarihleri arasında, Gülhane Askeri Tıp Akademisi Adli Tıp Anabilim Dalında yapılan ölü muayenesi ve otopsi raporları ile hasta dosyaları geriye dönük olarak incelenerek, yanığa bağlı ölümlerde saptanan postmortem bulgular ile antemortem klinik bulguların karşılaştııılması amaçlanmıştır.

BULGULAR: Yaklaşık 20 yıllık bir süre zarfında, 450 olgunun 3 I'inin (\%6.9) yanığa bağlı ölüm olduğu saptanmıştır. Yaralanmaların \%90.3 oranında alev yanığı sonucu meydana geldiği saptanmıştır. Olguların yanık yüzdesi oranı ortalaması \%70.52 olup bu oran arttıkça yaşam süresinin istatistiksel olarak kısaldığı saptanmıştır ( $r=-0.49$ l, $p=0.005)$. Otopsi bulgularına göre; antemortem olarak atlanan en sık klinik tanının pnömoni olduğu ve mortalitenin sistemik organ yetersizliklerine bağlı olduğu saptanmıştır.

TARTIŞMA: Yanığa bağı ölümler asker popülasyonu açısından önemli bir mortalite nedenidir. Otopsi ile ortaya konulan postmortem bulguların, yanık hastaların tedavisini yürüten klinisyenlere önemli katkılar sağlayacağını ve bu bağlamda disiplinlerarası veri paylaşımının önemli olduğunu değerlendirmekteyiz.

Anahtar sözcükler: Asker; otopsi; yanığa bağlı yaralanmalar.

Ulus Travma Acil Cerrahi Derg 2015;2I (6):49|-495 doi: 10.5505/tjtes.2015.36604 